\title{
Perianal-Perineal Localized Alveolar-Embryonal (Mixed) Type Rhabdomyosarcoma: Rare Localization, Case Report
}

\author{
Perianal-Perineal Yerleșimli Alveolar-Embriyonel (Mikst) Tip \\ Rabdomiyosarkom: Seyrek Yerleșim, Olgu Sunumu
}

\author{
Yasemin Durum¹, Hakan Maral', Mustafa Gök¹, Canten Tataroğlu² \\ 'Adnan Menderes University Faculty of Medicine, Department of Radiology, Aydın, Turkey \\ ${ }^{2}$ Adnan Menderes University Faculty of Medicine, Department of Medical Pathology, Aydın, Turkey
}

\begin{abstract}
A 17-year old girl who had been admitted to another hospital with perianal swelling and pain was diagnosed with perianal abscess. She had been given anti-biotheraphy and anti-inflamatory medication. Because her swelling and pain got worse, she was referred to our pediatric clinic. After her physical examination, she was prediagnosed with perianal abscess/tumor, and reffered to our department for magnetic resonance imaging examination, after which she was diagnosed with perianal tumor, and biopsy was performed. Alveolar-embryonal (mixed) type rhabdomyosarcoma (RMS) was diagnosed in the histopathology. Even though RMS is diagnosed frequently in childhood and adolescence, perianal and perineal location for this tumor is relatively rare. We wanted to highlight the rare localization and possible differential diagnosis for this type of tumor.

Keywords: Magnetic resonance imaging, perineal, perianal, rhabdomyosarcoma
\end{abstract}

\section{ÖZ}

Perianal şişlik ve ağrı şikayeti ile apse tanısı alarak izlenen 17 yaşında kız olgu şikayetlerinin geçmemesi ve şişliğin giderek büyümesi üzerine hastanemiz çocuk hastalıkları bölümüne başvurdu. Yapılan fizik muayene sonucunda perianal apse/kitle ön tanısıyla bölümümüzde uygulanan manyetik rezonans görüntülemede perianal/perineal kitle saptanarak yapılan biyopsi ile alveolarembriyonel (mikst) tip rabdomiyosarkom (RMS) tanısı aldı. RMS, çocukluk ve adölesan döneminde en sık izlenen yumuşak doku sarkomu iken, perianal ve perineal yerleşim oldukça nadirdir. Burada nadir bölge tutulumunu vurgulamayı ve apse gibi farkı klinik ön tanının malignite göstergesi olabileceğini hatıllatmayı amaçladık.

Anahtar Kelimeler: Manyetik rezonans görüntüleme, perineal, perianal, rabdomiyosarkom 


\section{Introduction}

Rhabdomyosarcoma (RMS) is a common mesenchymal originated soft tissue tumor in childhood (1-3). The age specific incidence rates of RMS show a bimodal distribution, with the first peak between the ages 2-6, and the second peak between 15-19. The most common location for RMS is the head and neck region with $40 \%$ incidence (1). Even though RMS is a common soft tissue sarcoma seen in the childhood and adolescence periods, the perianal and perineal location in genitourinary RMS subgroup is rare with less then a $2 \%$ incidence rate (4-6). RMS has four histological types being the embryological, alveolar, botryoid, and pleomorhic. Although in all locations the most common histological type is embryonal; for the perineal region it is the alveolar type (4).

For diagnosis, age, location, clinical-laboratory findings, local invasion, and metastasis are considered. At the time of diagnosis the metastasis rate is $10-20 \%$. The primary imaging modality is magnetic resonance imaging (MRI).

Treatment of RMS needs a multidisciplinary approach involving radiotherapy, chemotherapy, and surgery. Here, we present a case of perianal/perineal RMS, considered as perianal abscess after the first evaluation. With this case, we aimed to emphasize the rare location for RMS, and the fact that different pre-diagnoses such as abscess may be indicative of malignancy.

\section{Case Report}

A 17-year-old girl was admitted to the pediatric clinic in another center with a complaint of swelling in the anal region for the last 6 weeks. After the first evaluation, the drainage was planned with the diagnosis of pearianal abscess and during the intervention. During the drainage intervention, there was no infected material and hyperemic mass lesion was observed. The patient was referred to our pediatric department for further evaluation. The first examination at the department of pediatric oncology in our center revealed anal mass accompanied with pain. Erythrocyte sedimentation rate was slightly elevated, and lactate dehydrogenase was detected in the blood. C-reactive protein level was normal. Her pelvic MRI, which was obtained from her first admission, showed an ill circumsribed mass in the perianal region. Because of the non-contrast pelvic MRI protocol from the first admission, and the time interval with the new symptom (pain), we performed the abdominal MRI protocol with contrast medium in our department using Philips Achieva 1.5 Tesla MR machine. The abdominal MRI revealed a subdermal soft tissue mass located in the right ischiopubic fossa, $9 \times 8.5 \mathrm{~cm}$ in size, ill circumscribed, and disrupting the anterior borders between the rectal distal segment-anal canal-anus, isointense with muscle in T1 weighted images (T1WI), hyperintense in $\mathrm{T} 2 \mathrm{WI}$, which was heterogeneous and poorly contrasted (Figures 1, 2 and 3). Ultrasound (USG) guided fine needle Tru-cut biopsy was performed. Microscopic review showed a partially diffuse growth pattern and a partially alveolar tumor tissue filling all areas (Figure $4,5)$. In some regions tumor cells are rabdomyoblastic and in some regions they are round cells. For this reason, our case was diagnosed as alveolar and embryonal type RMS. Immunohistochemically, tumor cells showed nuclear staining with Myo D1 and cytoplasmic staining with Desmin (Figure $6,7)$. Because of the location and the extention of the tumor, our case was not eligible for surgery, so chemotheraphy with ARST 0431 protocol (ifosfamide, etoposide, vincristine, doxorubicin and cyclophosphamide) was started, and on the 20th week of the treatment one session of radiotheraphy was performed. In the follow up a marked regression was detected in the tumor. The treatment and follow up are still ongoing.

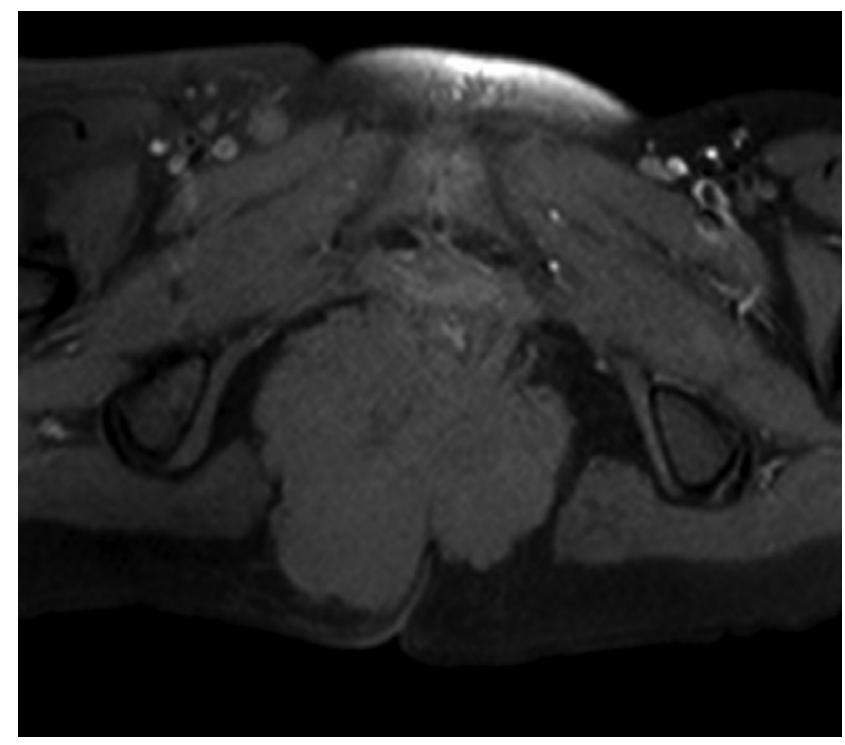

Figure 1. Axial T1 weighted magnetic resonance imaging image shows poorly defined mass in the perianal region

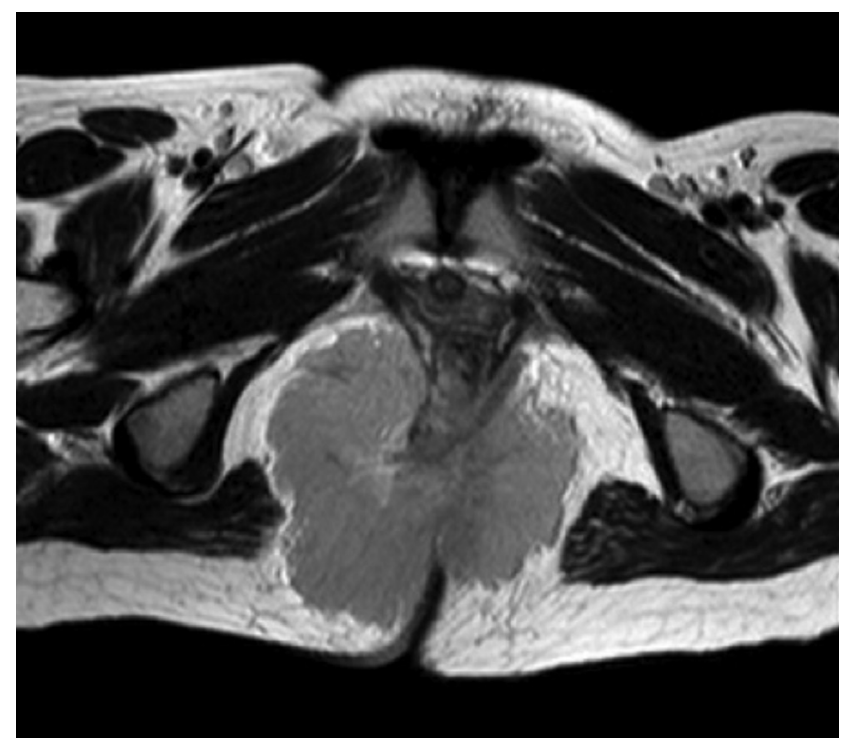

Figure 2. Mass is hyperintense on axial T2 weighted magnetic resonance imaging image 


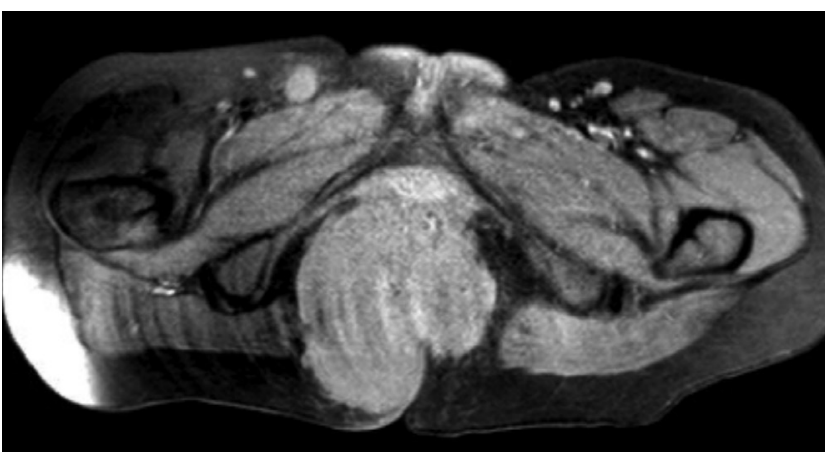

Figure 3. Axial post-contrast T1 weighted image shows homogeneous contrast enhancement of the mass

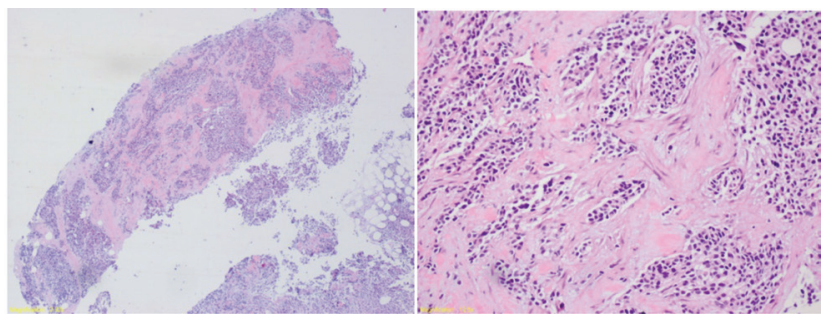

Figure 4, 5. Tumor tissue shows alveolar and diffuse growth pattern for rhabdomyosarcoma

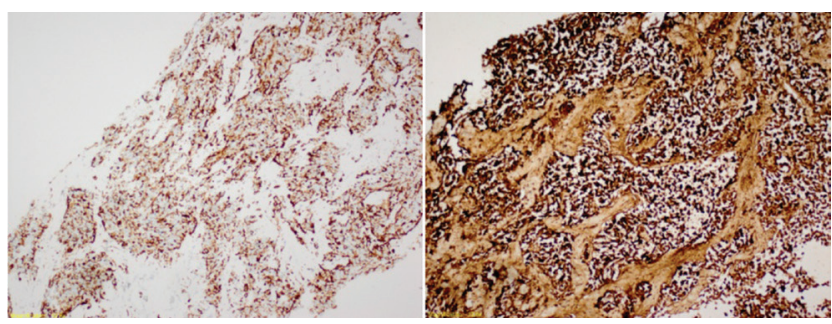

Figure 6, 7. Immunohistochemically tumor cells show nuclear staining with cytoplasmic Myo D1 with Desmin

\section{Discussion}

Although RMS is a common soft tissue sarcoma of childhood and adolescence, perianal and perineal location is very rare $(5,6)$. RMS in this location is thought to originate from the muscle layers of the intestinal and genitourinary tract.

For diagnosis a complete blood count and urine test must be done, and tumor markers from blood should be taken. USG, computerised tomography and MRI should be performed according to physical examination signs. Definitive diagnosis is based on histopathology. According to the literature, perineal RMS is mostly the alveolar type (4). Alveolar RMS is a generally ill circumsribed, locally aggressive and oval or round shaped tumor (7). In our case, the histopathology of the tumor was reported as embryonal/ alveolar type.

Perineal/perianal RMS has a high rate of misdiagnosis, especially in terms of infectious and inflamatory pathologies such as perianal abscess. Although there is no underlying disease in most cases, it has been shown that RMS is associated with neurofibromatosis, fetal alcohol syndrome, congenital central system anomalies (8). No relationship to any known disease has been detected in our case.

In MRI, like many other soft tissue tumors, RMS is midintense in T1WI, mid-hyperintense in T2WI. In other words, the imaging properties of RMS are non-specific. The tumor can be lobulated and multi-septated. The imaging findings of our case are consistent with the literature.

The differential diagnoses of RMS are quite broad because of its placement in many different anatomical areas. This broad differential diagnosis list includes; hemangioma, vascular malformations, adult type soft tissue sarcomas, primitive neuroectodermal tumor, infantile fibrosarcoma, desmoplastic small round cell tumors, rabdoid tumor, nonosseos Ewing's sarcoma.

Although the perianal/perineal region is rare for RMS with no particular imaging findings, it should be considered in the differential diagnosis for perianal/perineal tumors of childhood, and it should be kept in mind that it may interfere with perianal abscess.

\section{Ethics}

Informed Consent: Consent form was filled out by the participant.

Peer-review: Externally peer-reviewed.

\section{Authorship Contributions}

Surgical and Medical Practices: Y.D., Concept: Y.D., Design: Y.D., Data Collection or Processing: Y.D., H.M., C.T., Analysis or Interpretation: Y.D., H.M., M.G., Literature Search: Y.D., Writing: Y.D., M.G.

Conflict of Interest: No conflict of interest was declared by the authors.

Financial Disclosure: The authors declared that this study received no financial support.

\section{References}

1. Agrons GA, Wagner BJ, Lonergan GJ, Dickey GE, Kaufman MS. From the archives of the AFIP. Genitourinary rhabdomyosarcoma in children: radiologic-pathologic correlation. Radiographics 1997;17:919-37.

2. McCarville MB, Spunt SL, Pappo AS. Rhabdomyosarcoma in pediatric patients the good, the bad, and the unusual. American Journal of Roentgenology 2001;176:1563-9.

3. Dénes FT, Duarte RJ, Cristófani LM, Lopes RI. Pediatric genitourinary oncology. Front Pediatr 2013;16:1-48.

4. Van Rijn RR, Wilde JC, Bras J, Oldenburger F, McHugh KM, Merks JH. Imaging findings in noncraniofacial childhood rhabdomyosarcoma. Pediatr Radiol 2008;38:617-34.

5. Fletcher $B D$, Kaste SC. Magnetic resonance imaging for diagnosis and follow-up of genitourinary, pelvic, and perineal rhabdomyosarcoma. Urologic Radiol 1992;14:263-72.

6. Hill DA, Dehner LP, Gow KW, et al. Perianal rhabdomyosarcoma presenting as a perirectal abscess: A report of 11 cases. J Pediatr Surg 2002;37:576-81.

7. Parham DM, Ellison DA. Rhabdomyosarcomas in adults and children: an update. Arch Pathol Lab Med 2006;130:1454-65.

8. Kim EE, Valenzuela RF, Kumar AJ, Raney RB, Eftekari F. Imaging and clinical spectrum of rhabdomyosarcoma in children. Clin Imaging 2000;24:257-62. 